\title{
The need for leadership in gender justice: Advancing a missiological agenda for the church in Swaziland
}

\author{
Author: \\ Chammah J. Kaunda ${ }^{1}$ \\ Affiliation: \\ ${ }^{1}$ School of Religion, Philosphy \\ and Classic, University of \\ KwaZulu-Natal, South Africa \\ Correspondence to: \\ Chammah Kaunda \\ Email: \\ pastorchammah@gmail.com \\ Postal address: \\ Private Bag X01, Scottsville \\ 3209, South Africa \\ Dates: \\ Received: 13 Mar. 2014 \\ Accepted: 23 July 2014 \\ Published: 28 Nov. 2014 \\ How to cite this article: \\ Kaunda, C.J., 2014, 'The \\ need for leadership in \\ gender justice: Advancing a \\ missiological agenda for the \\ church in Swaziland', Verbum \\ et Ecclesia 35(3), Art. \#1346, \\ 9 pages. http://dx.doi. \\ org/10.4102/ve.v35i3.1346

\section{Copyright:} \\ (C) 2014. The Authors. \\ Licensee: AOSIS \\ OpenJournals. This work \\ is licensed under the \\ Creative Commons \\ Attribution License.
}

Underpinned by missiological thinking, the article argues that, in a context searching for gender justice, the mission of God should begin with making sensitive the consciousness of Swazi church leaders who, in turn, would act as agents for transforming social consciousness. In this process, the leaders become critically aware that they are called to act as prophetic example by adopting a gender-sensibility posture and calling the local church to account for its reluctance and slothfulness in teaching and practicing gender-justice values and ideals as one of the key social organs of the country. In addition, the leaders should become conscious of the fact that they have a wider prophetic missiological task to subversively challenge and wisely remind the State about its social responsibility to advance the socially shared agenda of radically promoting the rights, humanity and dignity of women in its domain.

\section{Introduction}

I begin with a question: What sort of leadership does the church in Swaziland need in the 21st century? This question is critical, given the fact that church leaders have played an ambivalent role in the history of human progress. On the one hand, leaders have been key in harnessing and mobilising resources for social change and development. On the other hand, history and feminist theologians provide perspective on the subject and reveal the negative role that church leaders have played in sanctioning gender '... discriminating practices upheld by divine authority' (Mwaura 2005:410-445; Sundkler \& Steed 2000:679). They have reminded us that leadership is not neutral, and its nature is inextricably political, and they are calling for leadership paradigms to be challenged, deconstructed and reconstructed, based on the specific context and crucial issue(s) of the moment. Thus the above question can be adequately answered by relating it to the momentous social challenges facing the church in Swaziland.

One such challenge is that Swaziland continuous to experience high levels of gender injustice and inequality and has attracted negative international attention in this regard (Langwenya 2013; Mabuza 2013). ${ }^{1}$ To some extent, the persistence of every social challenge highlights the prevalent leadership style in that particular context. The perpetuation of discriminating gender practices in Swaziland points to a leadership culture deeply entrenched in androcentric or misogynistic consciousness, a state which can only be overcome by constructing an alternative leadership imagination. The question is therefore not whether there are church leaders in Swaziland, but what kind of church leaders are needed to generate consciousness regarding gender justice?

The interest is not just in leadership for its own sake, but in the kind of leadership styles that can stimulate, motivate and be innovative in the lives of the people to enable them to respond subversively to gender injustice in the nation. Unfortunately, the church leaders in Swaziland appear to have resigned to the pulpit and to some extent remain trapped in the clasp of Swazi traditional leadership and classical forms of church leadership introduced by the Western missionaries in the 20th century. They appear to proclaim the gospel of life without sensitivity to gender justice and without understanding the social implications of the gospel, that is, proclamation as a social act - preaching in contradiction. Proclaiming the gospel signifies that if one denies the humanity and the human rights of women or, for that matter, any person, one is essentially denying the whole community. The following questions can be raised: What kind of moral consciousness should shape church leaders in the context that demands gender justice in Swaziland? Are integrity and good intentions enough in occasioning the transformation of gender justice and social attitudes? There are no easy answers to such questions. They can be approached from different angles, depending on the objectives of the article. In the case of this article, the aim is to show that to develop a leadership style and attitude that is sensitive to gender

1.The 2013 general elections highlighted continuing gender inequality in Swaziland. In 55 constituencies, only one woman was elected The King also nominated only three additional women to the lower chamber of parliament. Whilst the constitution provides for increasing the number of women in strategic leadership positions, it seems to be ignored when the opportunity presents itself (Foreign \& Commonwealth 2014). 
justice is not only critical but a more viable way of responding effectively to the issues of gender injustice and inequalities in Swaziland. I return to the two questions above.

\section{A missiological perspective}

This research builds on a missiological perspective as its particular interpretive approach. The theoretical inquiry begins with a political commitment to shape missiological leadership with a critical consciousness to foster principles of human rights, dignity and worth and religious, economic and socio-political transformation (Burns 1978:4). The logic proceeds by constructing or unveiling underlying meaning and making sense of knowledge as a means for envisioning gender justice in a particular context (Phiri \& Nadar 2010:8-24). Underpinned by missiological consciousness, this article rationalises church leadership as God's missiological resource working for gender justice. The logic is also indebted to Nico Botha's (2009) lucid definition of the missiological perspective as:

... a faith perspective which sees the Trinitarian God as a God in mission who responds to the humanly constructed world in terms of redescribing ... it and indeed changing it. The church, as one of the signs of how the Trinitarian God is constantly working at manifesting and establishing God's reign in the world, is called upon to be a church in mission by equally re-describing and reconstructing reality. (p. 3)

In this perspective, leadership in gender justice can be understood as missiological praxis that redescribes the world in relationship to God's mission by challenging dominant and hierarchical readings of social realities. The missiological imagination addresses issues of gender justice as well as sociocultural, political and economic issues in an intersectional fashion rather than as isolated issues (Pui-lan 2004:24).

From a missiological perspective, Pui-lan (1996) claims that to be a leader for gender justice:

... is to proclaim the good news that God affirms life over death and that God acts among the poor, the majority of whom are women who are victimized in the globalization of the market economy and left out in decision-making processes. (pp. 185-186)

Based on this definition, playing a leadership role in gender justice as missiological praxis contains three essential components: Firstly, mission-logic is a prophetic praxis. It is both the intrinsic nature of God as who God is and the transforming action of God in the world as what God does through human agents. Due to pervasive gender injustice as one of the key factors contributing to social degradation in Swaziland, any meaningful missiological response should begin with gender justice as one of the underlying implications of Jesus' prophetic missiological consciousness is to bring the good news of abundant life to the oppressed and to proclaim religious, political and economic liberty to the exploited (Is 61:1ff.; Lk 4:18ff.). Secondly, it follows that mission-logic is contextually defined and situated. It reflects the socio-cultural and political economy of the environment in which it is practiced. God's mission in the context of gender justice is not isolated from the '... shared agenda of social, cultural, economic and political transformation for equality and the realization of human rights for all' (Pui-lan 2004:24). Thirdly, a mission-logic perspective is inherently political. It analyses the systematic forces of socio-economic, cultural and political realities and the dominant ideological lens that informs such gender injustice. Thus, this article appraises from a missiological perspective the implications for church leadership of the body of writings emerging from the Swaziland context, calling for gender justice.

\section{Gender injustice as catalyst for leadership in gender justice}

From inception, the church has always responded to the social sins of political oppression, economic exploitation and cultural alienation in order to inaugurate the reign of Christ. Yet African women scholars have also documented the negative role that the church has played in promoting and perpetuating discriminatory gender practices and religious and ideological persecution (Mwaura 2005; Njoroge 2000; Oduyoye 1986; Phiri 1997). Through rationalisation of social hierarchies, the church has also been the chief cause of racial segregation, resulting in political repression and economic dislocation in the 20th century (Éla 1988; Katongole 2002; Mugambi 1995).

Nevertheless, the abuse of Christianity and its sacred book by fundamentalist forms of leadership cannot negate the fundamental message of the gospel that God created the world and human beings for freedom, dignity, justice and equality. The prophet Amos (5:7, 15, italics added) indicted to the leaders of Israel that '... you that turn justice to wormwood, and bring righteousness to the ground! ... Hate evil and love good, then work it out in the public square'. This verse reveals that the health of the public is dependent on the prevalent model of leadership in the public sphere. When one glances through the prophetic books in the Old Testament of the Hebrew Bible, it becomes clear that the social sins concerning leadership were the underlying cause for prophetic responses. In the same way, the overwhelmingly and seemingly persistent gender injustice provides the church leaders in Swaziland with an unprecedented opportunity for a major breakthrough in developing the moral consciousness of their society. Indeed, gender justice is a moral issue. The struggle for gender justice cannot be realised without the leadership in Swaziland being conscious of gender justice.

\section{An ambivalent constitution and gender inequality}

Swaziland became interdependent in 1968. At the same time, King Sobhuza II cancelled the independence constitution, instituted a traditional system of governance known as the Tinkundla, assumed full executive power, retained the position of the traditional advisers to the King, strengthened the legislative and judicial power and banned political parties. He also confirmed that Swazi customs would take supremacy over any contrary human-rights obligations (Kalley 2003:4-5). The Tinkundla system, recognised in the current constitution, endorses the powers of the king 
and stipulates that candidates standing for election into parliament must be independent of any political parties (Kalley 2003:4). In this way, the King as Ngwenyama [Lion] has almost absolute power over the system of governance as the custodian of the customary law of Swaziland.

Whilst the Constitution of the Kingdom of Swaziland (2005:11, section 2[1]) has been declared 'the supreme law' of the land, Swaziland has a dual legal basis. Firstly, there is a system which is based on the so-called 'Western Constitution', based on Roman-Dutch law and constitutive of 'civil law' which is controlled by the Magistrate's court and the High Court. Secondly, alongside this system functions Swazi customary law (also known as 'Swazi Law and Custom') '... which is enforced through the customary courts or "Swazi Courts"' (Manson 2008:10). The customary law may in most cases supersede the so-called 'Western law'. In fact, even the socalled 'Western Constitution' (Constitution of the Kingdom of Swaziland 2005) gives the King radical immunity from:

(a) suit or legal process in any cause in respect of all things done or omitted to be done by him; and (b) being summoned to appear as a witness in any civil or criminal proceeding. (p. 14, section 11)

This itself negates the notion that the Constitution is the supreme law of the land because the King is untouchable. In fact, he is the highest law of the land. The King can manipulate laws to his advantage, but no one can query him or subject him to prosecution since the Constitution protects him. This position is very dangerous for a nation that calls itself democratic. The Swaziland monarch seems to have power over the Constitution. Currently, concern is being voiced with regard to the need for the monarch to respect the independence of the judiciary and the rule of law (International Bar Association 2013:3). In addition, the Constitution has no clear provision for the right to access to public information. Democracy is more than mere consultations - it is more about who holds the power. It is about affirming the capacity of the people to govern their nation through sharing power as equal citizens mutually guided by accountability and radical checks and balances (International Bar Association 2013:25).

Whelpton (1997:147) argues the Swazi customary law refers to '... the social relationships and social actions which take as their point of departure age-old customs validated by the ideology of traditionalism and legitimised by the king'. Whilst the custodians of Swazi customary law are aware of the dynamic tradition, they are not willing to accommodate the changing social values which should have consequence on the law itself because they benefit from the system. In this way, Swazi customary law seems to take pre-eminence and '... takes on a much more overt political dimension ...' than in most countries in sub-Sahara Africa (Manson 2008:9). On the one hand, the customary law is subject to the provisions of a Bill of Rights in the Constitution, which implies that the principles and conditions of Swazi customary law may be challenged by the guarantees of human rights such as gender justice and equality (Van Schalkwyk 2006). On the other hand, it works as a mechanism '... in which gender relations are subjected to the powerful ideological and political forces surrounding legal systems of governance and national identities' (Manson 2008:4). In addition, although there was a process to codify customary law, and it is reported that the document has been ready for over a decade, the committee was disbanded and the prince who was in charge stressed that he had '... no authority or official capacity with which to present it to the King' (Magagula cited in Manson 2008:14).

Scholars observe that a critical stress on customary law in Swaziland has reinforced and perpetuated negative perceptions of women as inferior to and less human than men (Langwenya 2013; Manson 2008; Van Schalkwyk 2006). As a consequence, Swazi women have very limited access to their rights such as the ability to own land, inherit property, find employment and even conduct business. Indeed, it has been documented that the victimisation and marginalisation of women remains one of the most serious aspects of social injustice in the present day Swaziland (Association of Corporate Treasurers of Southern Africa [ACTSA] 2010:10). Theoretically, the Constitution of the Kingdom of Swaziland subscribes to the fundamental ideals of democracy such as upholding human rights and respect for the rule of law at both national and international level. It (Constitution of the Kingdom of Swaziland 2005) guarantees the rights and freedoms of women as follows:

(1) Women have the right to equal treatment with men and that right shall include equal opportunities in political, economic and social activities; (2) Subject to the availability of resources, the Government shall provide facilities and opportunities necessary to enhance the welfare of women to enable them to realise their full potential and advancement; (3) A woman shall not be compelled to undergo or uphold any custom to which she is in conscience opposed. (p. 31)

Despite this provision in the Constitution, analysts argue that this is not reflected in empirical life and many laws and practices in Swaziland remain gender biased (ACTSA 2010:10). ACTSA (2010) argues that:

Despite the new Constitution, old laws have remained on the statute books so that in many areas women are still treated as minors. To obtain bank loans, for example, many banks still insist that women must obtain a signature from their husbands. Women cannot own property under inheritance laws all marital property goes to the deceased husband's family. In the beginning of 2010, Swaziland's High Court ruled that some married women should legally be entitled to register property in their own name, which was celebrated as a small success by women and activists in the country. This was, however, reversed three months later by the Supreme Court. (p. 10)

The priority given to Swazi customary law over human rights and humanity of women raises a fundamental question for the Swazi legal system: '[I]s it possible for the country to honour its international legal obligations while at the same time preserving and upholding traditional customary norms in their present form' (Langwenya 2013:7). The solution does not lie in calling Swaziland to abandon its customary law. Rather, the call should be to bring it in dialogue with human rights and the democratic ideal in order to develop contextual human rights that would promote the humanity and wellbeing of Swazi women. 


\section{Gender injustice: Birth pangs for consciousness concerning leadership in gender justice}

At the recent 57 th Session of the Commission on the Status of Women held in New York, the Principal Secretary to the Deputy Prime Minister of Swaziland, Khangeziwe Mabuza (2013), lamented that:

In Swaziland, gender based violence is one of the social challenges that affect women and girls disproportionately. The Multiple Indicator Cluster Survey (MICS 2010) find[ing]s show that among women age 15 to 49 years, 1 in 5 is beaten by [the] husband or partner; whilst among men of the same age, 1 in 200 is beaten. (p. 1)

Mabuza (2013:2) added that, despite the fact that sexual violence infringes on their right to dignity and health such as sexual and reproductive health - and makes them more susceptible to HIV infection, the majority of Swazi women prefer to remain in unhealthy relationships due to economic reasons. This is exacerbated by contradictions in the Constitution. For example, Maxine Langwenya (2013) exposes that:

The right to gender equality, in that Swazi common law assigns women married in community of property the status of minors, and discriminates against women married to non-Swazi nationals with respect to the citizenship rights of their spouses and children. International norms on gender equality are also contradicted by some rules of customary law, for example those that deny women equality with men with respect to marital and reproductive rights. (p. 4)

It is important to mention that Swaziland is classified as a low middle-income country, with a per capita income of approximately $\$ 1350$, over twice the sub-Saharan average (ACTSA 2010:6). Whilst this per capita income can cater for the whole population of the country, much of the resources fall into the hands of the ruling elite who are mostly men. The World Health Organization (WHO 2012) reports that income is unevenly distributed in the country. As a result, the majority of people, who are mostly women and children) estimated at $63 \%$ in 2010) live in abject poverty.

There has also been an increase in unemployment from $22 \%$ in 1995 to $29 \%$ by 2010 . The WHO (2012) adds that the spread of the HIV and AIDS epidemic continues to pose a major threat to the health of the Swazi nation. It is estimated that between 210000 and 230000 (about a quarter of the population of just over a million) people (mostly women and children) are living with HIV and AIDS in Swaziland. 'The prevalence rate among pregnant women has escalated from 3.9\% in 1993 to $41 \%$ in 2010 , having reached a peak of $42.6 \%$ in $2004^{\prime}$ (WHO 2012). The maternal and infant mortality rate is high, the 2010 survey estimated at 79 per 1000 live births. This means that of every 1000 newly born babies, 79 do not survive to 12 months of age. There are variations in statistics in different reports, but the heart of the matter is that women's health is a serious issue in Swaziland. The current statistics show that a fifth of the population is orphans and vulnerable children (OVC) (Integrated Regional Information Networks [IRIN] News 2011).
One can argue that such an injurious picture of a society does not frighten leaders in gender justice but presents itself as an opportunity, a kairos moment, a favourable window of opportunity filled with danger and possibilities. True leadership is tested in the way it responds missiologically to the contradictions and life-denying circumstances. The increase in gender injustice and human-rights abuses also increases the demand for leadership in gender justice. In the same way in which the inhuman situation on the cross of Calvary presented Jesus with an opportunity to confront human injustice once and for all, leaders in gender justice can thrive in the midst of contradiction. If there were no societal challenges such as gender injustice and inequality, there would have been no need for such leaders. The question remains: Where is the prophetic voice of the church in Swaziland against gender injustice? It is only when leaders consciously and decisively choose to confront the fundamental injustice of a system that privileges the minority at the expense of the masses that the nation can begin to experience wholeness. How can this be done? Ultimately, this is a question of constructing leadership in gender justice at all levels of society.

John Maxwell (2007:v-vi) has rightly argued that '... everything raises and falls on leadership'. It is the leaders that determine the destiny of their nation. The church leaders are called to be a gender-justice consciousness of the society as God's missiological agents for liberation and national formation. The context of Swaziland needs leaders in gender justice who can lead their society to wellbeing and peaceful living. This raises questions: What are some of the characteristics of leaders in gender justice? Or rather, what kind of leadership style can be categorised as supportive of gender justice? What characteristics should the leadership possess in order to respond appropriately to gender issues in Swaziland?

\section{Leadership in gender justice: What kind of leadership?}

To begin with, leaders in gender justice envision an alternative society based on the principles of a just and equitable society. They uphold the church's prophetic responsibility to proclaim the kingdom of God in words and deeds by contextualising and applying its public teaching to concrete human experiences. This approach to gender justice requires more than just integrity and pious intentions in the leaders (Antrobus 2002:47). There are many characteristics that are needed in leadership in gender justice, but here I suggest only five of them.

Firstly, leaders in gender justice recognise the complexity of the task, the interconnectedness of gender injustice with economic, religious, political and social systems and the obligation to address all of these issues in their interconnectedness. One cannot deal with the issues of gender injustice and inequality without, at the same time, confronting economic and political issues which are sanctioned and perpetuated by social systems such 
as cultural and religious practices and beliefs. In other words, leaders in gender justice should avoid offering Band-Aid solutions to problems by confronting the cause of the problem, not the symptoms. Symptoms are not the problem but the manifestation of a deep-rooted problem. One can deal with the symptoms only temporarily because symptoms are only a sign of the greater problem.

The apostle John (Jn 1:29) depicts Jesus as the Lamb of God who takes away the sin of the world. Jesus came as the Lamb of God to confront the cause, which is 'sin'. Note that 'sin' (hamartia) in this verse is singular and not plural (sins). John uses the word '... 'the Sin' not to describe the actions or results (sins [plural] which are committed) but to describe the underlying root cause, the basic principle' or the entity (Precept Austin n.d, bold and italics original). Clearly, the sins are the manifestations of the sin which works like an abnormal gene transmitting a defective moralethical code. This entity is so strong that human beings have no control over it except to bow down and commit sins (plural). In other words, human beings commit sins because of the $\sin$. The sin is the very essence from which sins spring, and that is why Jesus came to destroy its hold over human beings so that they no long have to be slaves of the sin. St. Paul $(\mathrm{Rm} 6: 14,18)$ makes it clear that '... sin shall not be your master ... you have been set free from sin and have become slaves to righteousness'.

In the same way, issues of violence against women or the absence of women in strategic leadership positions in society are only symptoms that point to a serious problem of a particular society's perception of women as inferior or subhuman. In short, issues of gender inequality and injustice are only a sign or manifestation of the greater underlying root cause of a sick society in desperate need of healing. The society cannot claim to be whole when the rights and the humanity of the majority of its people have been denied either intentionally or unintentionally. It is important, therefore, that the leaders in gender justice do not take it for granted that they know the problem of their society or that they understand the dynamics of their cultural beliefs and practices. Leaders in gender justice must be well informed by social analysis in order to challenge male power that lies at the root of other forms of social injustice and oppression that subjected women to perpetual male hegemony.

Secondly, leaders in gender justice are the moral consciousness of their society. Joy Phumaphi and Lord Carey (2007:xi) have argued that '... we understand well, from the different perspectives of our contrasting backgrounds and present missions, that [gender injustice] and inequity [are] matters of conscience', The conscience is the human mechanism for checks and balance in order to occasion gender justice. It is the inner power of thought which enables human beings to distinguish between morally good and bad, upholding the good and condemning the bad. Martin Luther King Jr. (1967) stresses that, when it comes to moral consciousness of social evils:
... a coward has asked the question is it safe? Expediency asks the question, is it politic? Vanity asks the question, is it popular? But conscience asks the question is it right? And there come a time when one must take a position that is neither safe nor politic nor popular but he [sic] must take it because conscience tells him [sic] it is right. (s.p.)

It is the leader's moral consciousness and awareness that work as a tool for calling for radical gender justice. Yet the Bible also warns that conscience can be seared or cauterized (1 Tm 4:2). Indeed, Willard Gaylin (1973:167-194) writes that '... the failure to feel guilt is the basic flaw in the psychopath, or antisocial person, who is capable of committing crimes of the vilest sort without remorse or contrition. Therefore, the leader in gender justice desires to nurture a gender-justice oriented moral consciousness, fuelled by a passion to make society a better place that can morally discern the difference between right and wrong. Such a leader is passionate about upholding the principles of justice and equality to govern their moral decisions (Mackay cited in Branson 2007:472).

Thirdly, leaders in gender justice are socially gendered beings in the community with a mission to uphold gender justice. Through the ages, as long as humanity can remember, leaders have always been change agents. The leaders in gender justice are aware that change is an inevitable part of human life and can take its course unabated either for good or bad. Therefore, they are not threatened by consensus, but seek to mould consensus that reflects the justice of the reign of God's kingdom (King 1967). They are motivated by the knowledge that gender justice demands that all individuals and their society experience a state of wellbeing and wholeness '... of physical, mental, spiritual, economic, political and social wellbeing; of being in harmony with each other, with the material environment and with God' (Benn \& Senturias 2001:20). Diane Kennedy (2000) affirms that the theology of leadership in gender justice:

$\ldots$ is grounded in a conviction of the ever-creative newness of the Spirit at work within the church. The role of the leader is to support that transformation, but a conviction about the transforming power at work among us demands a willingness to live in the tension of resistance, deal with conflict, stay with the struggle, courageously face the questions, confront destructive behavior, and continually attend to the collegial process. (p. 63)

Fourthly, leaders in gender justice are passionate about justice and committed to transformation, beginning with themselves (Antrobus 2002:49). Bringing about transformation in a society partly depends on the leaders' ability to transform themselves and their own relationships in society. The question may be raised: Can a church leader with a hostile attitude towards gender justice and equality help others to develop a sensitive attitude towards gender justice? It appears to me that a blind person cannot lead a fellow blind, ' $\ldots$ both will fall into a pit' (Mt 15:14). A male leader cannot transform gender injustice in society when it is pervasive in his own home. Justice is the heartbeat of God. A society without justice is a decaying society. The society does not exist to uphold the interests of a few but of everyone, especially the marginalised and the minority groups. It is 
in this that the health of the nation lies. King (1967) argues that '... injustice anywhere is a threat to justice everywhere'. Justice signifies the most crucial of the cardinal virtues. In fact, it can be considered as one of the basic human needs in contemporary Swaziland and Africa at large. In the Hebrew Old Testament, justice is embedded in the notion of peace, a comprehensive term enshrined in the word shalom, '... which means peace in fuller sense as wholeness, healing, justice, righteousness, equality, unity, freedom, and community' (Enns 2011). In short, shalom means a full life in life-enhancing and affirming relationships. Gender justice is concerned with transforming human sensibility and attitudes and with radically ordering social structures so that life can flow and so that the dignity and rights of women and men are radically and uncompromisingly affirmed.

Fifthly, leaders in gender justice are aware that the content of the gospel remain the same in every generation but the methods are ever changing. The world is in continuous transition, and secular people easily adapt to change. Yet the church does not easily adapt to these changes. Therefore, leaders in gender justice are always at the frontiers to find new ways of doing the mission of God in their particular context in relation to gender issues. To reiterate Botha's (2009:3) argument, the church is meant to manifest the workings of the Trinitarian God in the world by responding to 'humanly constructed world in terms of' reshaping it according to the origin plan. Botha (2009:3) stresses that God calls the church to participate in his '... mission by equally re-describing and reconstructing reality'. God is constantly working to undo injustice and redo justice in the world. It is important to understand that the church must constantly wrestle to be relevant in its context whilst remaining truthful to the gospel of Christ.

The mission of God remains the mission of the church and will never change, but methods of proclaiming the gospel are always changing and the church is repeatedly challenged to go back to the drawing board, seeking viable methods of responding to ever-changing contexts. The contemporary church in Swaziland has almost become obsolete because of its dependence on 20th-century methods of proclaiming the gospel. It is imperative, therefore, that leaders in gender justice understand the signs of the time and formulate viable methods for their specific context that can respond adequately to issue of gender in the 21st century. A critical question can be asked: What are the practical missiological principles that can guide the public engagement of the leaders in gender justice in the context of Swaziland?

\section{Framing missiological contours for leadership in gender justice in Swaziland}

It is my contention that leaders in gender justice are crucial for envisioning a society where human beings will not be judged by their gender but by their inherent values as human beings created to reflect the image of God. The realisation of this task raises four missiological principles to guide leaders in gender justice in their engagement in missio Dei in Swaziland.
The first principle is that the mission of God is a mission of wholeness. There is no way that the mission of God can be separated from the people's reconciliation, which is bringing critical balance between women and men for social wholeness and healing. The practical missiological implications of reconciliation are that the leaders in gender justice are called to create reconciliation between genders in a '... forum for women and men to jointly confront gender injustice and unravel the insidious knots of cultural conditioning and oppression relating to gender and sexuality' (Keepin \& Brix 2008:34). Jesus confirmed his mission that '... I have come that they may have life; and have it to the full' (Jn 10:10). Gender injustice and inequality is a disease which is destroying societal wellbeing in Swaziland. In Galatians (3:28, The Message, italics added), the apostle Paul argues that ' $[i] \mathrm{n}$ Christ's family there can be no division into Jew and non-Jew, slave and free, male and female. Among us you are all equal.' From the beginning of his ministry, Jesus expressed his mission as a mission of wholeness and wellness.

The incarnation of Jesus affirms that the church must engage in teaching and training for gender justice in the midst of this world with all its pain, brokenness and fragmentation. Also, health as a basic human need embraces all of human existence. In Luke (4:16-21), Jesus openly declared his unambiguous concern for the oppressed and marginalised and his desire to lead society into solidarity with any struggle for liberation and justice from the forces of oppression (World Council of Churches [WCC] 1991:35). Gender justice is holistically touching every aspect of the human being, not just the body but also mind, heart, spirit and the environment. Leaders in gender justice seek to apply spiritual teachings in the practices of their members, drawn from contextual values and practices such as proverbs and riddles.

The second principle is to develop a comprehensive vision of gender justice within the Swazi context. In responding to God's call for the church's involvement in gender justice, the underlying challenge is to understand the Swazi culture in relation to the unity of humanity and work towards creating societies where an intricate balance between female and male can be maintained. There are positive ways of expressing culture that are not ideological and subjugating but that enrich interconnectedness and equality of humanity. For instance, the Swazi metaphysic maintains the indivisibly of male and female or does not draw a sharp dichotomy between female and male. In this traditional thought, community wholeness is grounded in harmony, a principle which is fundamental to everything that happens in the community. Harmony is not only maintained within human relationships, but also at a spiritual and cosmic level. Wholeness is the totality of well-being and fullness of life in the present reality. Laurenti Magesa (1997:65) argues that each individual is obliged to maintain harmonious and peaceful relationships with all members of the community by maintaining equilibrium between God and humans, female and male, human being and environment. In case of breach, the individual is called upon to do what is necessary to repair it for the sake of harmony and to strengthen the community bonds, especially 
through justice and equality. This is a critical traditional resource that should inform the response of leaders in gender justice to gender injustice in Swaziland.

The third principle is to develop profound awareness for a gender-sensitive empirical attitude and lifestyle. In the majority of African countries, it is behaviour that influences people's health and wholeness. However, individuals in most African societies do not ultimately influence their personal lifestyle. They are engulfed in the web of social relations which are experienced within the web of religiocultural, socioeconomic and political environments. These aspects are interconnected and are in most cases consciously and unconsciously reinforced and perpetuated through the patriarchal system, an ideology based on male control over social organisation. This means that the overall strategic direction that the society takes is a result of a variety of public policies which have been tailored to benefit the ruling class. This makes individuals, especially women and children who lack power to determine their destiny, to live in a society where their behaviour and lifestyle is already to a large extent determined by the powerful. For instance, can a young girl who has been forced into an arranged marriage make choices for her lifestyle? Does a married woman have a choice over her lifestyle in the context where she has no cultural rights to negotiate condom use even when she is perfectly aware of her husband's infidelity? It is these wider causal factors that need to be addressed first if a difference is to be made in individual women's lifestyles. The public engagement of leaders in gender justice is not simply a matter of condemning injustice. Rather, it is about finding ways to give a voice to the marginalised and oppressed by helping them minimise personal exposure to situations of gender injustice.

According to the prophet Amos (5:22-24), the church fails God if it fails to affirm and uphold justice for women and children. God calls leaders to take seriously the issue of justice as fundamental to the human quest for health and wholeness. The mood of the above text reveals that God is dismayed beyond words at leaders who are turning justice into venom whilst oppressing, dehumanising, depersonalising and exploiting and simultaneously continuing in their religious attire. This is similar to having a Constitution (Constitution of the Kingdom of Swaziland 2005) that affirms that the dignity of every person is inviolable' and stresses that:

... all persons are equal before and under the law in all spheres of political, economic, social and cultural life and in every other respect and shall enjoy equal protection of the law ... a person shall not be discriminated against on the grounds of gender ... (pp. 22-23)

The leadership in gender justice can take advantage of this ambiguous provision in the constitution by beginning to implement the discourse in their local churches and availing themselves in public forums to a deal with public concerns and policies in order to a just and equitable voice to their formulation.

Disappointingly, the extent of discrimination against women raises confusion in Swaziland. There is enough evidence showing that Swaziland is one of the African countries that has faithfully signed and agreed to several vital continental and international documents which critically uphold and affirms women rights. Tenille Brown (n.d.) argues that:

Swaziland has acceded to the Convention on the Elimination of All Forms of Discrimination against Women, the International Covenant on Civil and Political Rights, and the International Covenant on Economic, Social and Cultural Rights. In addition Swaziland has ratified the African Charter on Human and People's Rights, and has [ratified] that Charter's Protocol on the Rights of Women. (p. 1)

On the one hand, such commitments are meaningless until the government is willing to respect and strengthen the rule of law (ACTSA 2010:10). On the other hand, this is an opportunity for gender justice to make women sensitive about such developments and also advocating for the radical implementation of these documents dealing with the rights of women.

Swaziland is a country that has a form of democracy, but is denying the power and ideals of democracy. It is a country that devours its own people whilst working hard to keep up appearances to outsiders. Indeed, what is written in the Constitution of Swaziland is not what it is practiced on the ground. Swaziland's commitment to international human rights is further brought into question by its retention of national laws that directly contradict even those international human-rights instruments to which it is a party. The question is: What is the purpose of having a Constitution that cannot be implemented to serve the rights of the oppressed and exploited?

It is important to highlight that the Constitution cannot implement itself, and it is in this locus that the leaders in gender justice can call the church to account as a social instrument that can spearhead the implementation of the Constitution and international human-rights agreements. It is the duty of leaders in gender justice to understand their Constitution and every international human-rights agreement to which Swaziland is a signatory in order to educate women about their rights and to be able to wisely engage in public discussion over gender issues. In this way, the leaders in gender justice can become critically informed about their Constitution and discover the inconsistences and weakness to engage in lobbying the government '... to adopt and implement a plan of action for comprehensively removing any inconsistencies between national laws and international human rights norms ...' and develop a more life-giving Constitution which can protect the rights of the marginalised (Langwenya 2013:5). Thus, the international human-rights agreements signed by Swaziland and the Constitution are to be perceived as critical resources for envisioning a gender-just Swaziland.

The fourth principle is that justice is a definitive character or an attribute of God embodied in human relationships and expressed in social life. Justice is the very essence of God, 
meaning that one cannot separate justice from the being of God. Justice is the prerequisite for healthy relationships, causing gender justice to be a precondition for social progress and wholeness. In the majority of African cultures, it is a wellknown fact that it is impossible to envision social wholeness and human progress in the midst of moral, gender, social and cosmic disorder. As argued above, the majority of African societies know no sharp distinction between woman and man. In these societies, the contemporary gender inequality and injustice is a breach in the harmony of relationships which demands repentance and reconciliation. Justice is what held the African community in the bond of peace, health and wholeness.

This demand for justice is at the heart of the prophetic tradition in the Old Testament of the Bible. The imagery used for 'justice' in Amos 5:24 shows that God's justice is ultimately about healing and the wholeness of every human being. It is about affirming life: 'I want justice - oceans of it. I want fairness - rivers of it.' Therefore, instructions in justice and wholeness should be at the heart of the proclamation of the gospel by leaders in gender justice.

If the Swazi people want to build a healthy society, they need to reflect and revaluate Swazi culture in order to find elements that can contribute to promote gender justice and equality to help the church in understanding and addressing the root problem of gender inequality and illness. There is a need to involve the community members in the process of finding appropriate solutions to the escalating issues of maternal and infant mortality. Social problems can only be solved once the church has developed strong partnerships with community members. The church cannot afford to surrender the ministry of health and wholeness to Non-Governmental Organisations (NGOs) and government agencies. In this context, leaders in gender justice have a duty to develop educational programs within their local churches, aiming at raising the awareness of women and the society about the practical implications of the biblical meaning of justice in the context that demands gender justice.

\section{Conclusion}

The article argued that leaders in gender justice are desperately needed in the context of Swaziland to spearhead the call to reduce gender injustice and inequality. They are needed to take centre stage in the fight against discrimination and gender-based violence. The task of the church is not only to prophetically remind the government to fulfil the promises made to the people but to become an instrument of gender justice and equality itself by finding viable ways of implementing within their local churches and community the Constitution and the international human-rights agreements of which Swaziland is a signatory. The church has an eternal mandate to inaugurate the reign of the Kingdom in the world and, as such, cannot leave issues of eternal value such as gender justice in the hands of a fragile and transient human institution such as the Swazi state.

\section{Acknowledgements Competing interests}

The author declares that he has no financial or personal relationship(s) which may have inappropriately influenced him in writing this article.

\section{References}

Association of Corporate Treasurers of Southern Africa (ACTSA), 2010, 'ACTSA briefing paper Swaziland, September 2010', viewed 21 August 2013, from http://www. actsa.org/Pictures/Uplmages/pdfs/ACTSA\%20

Antrobus, P., 2002, 'Feminism as transformational politics: Towards possibilities for another world', Society for International Development 45(2), 46-52.

Benn, C. \& Senturias, E., 2001, 'Health, healing and wholeness in the ecumenical discussion', International Review of Mission 90(356/357), 7-25. http://dx.doi. org/10.1111/j.1758-6631.2001.tb00256.x

Botha, N., 2009, 'John Calvin in missiological perspective: On church unity and social justice', Studia Historiae Ecclesiasticae 35(2), 1-16.

Branson, C.M., 2007, 'Improving leadership by nurturing moral consciousness through structural self-reflection', Journal of Education Administration 45(4), 471-495. http://dx.doi.org/10.1108/09578230710762463

Brown, T., n.d., 'Women's legal status under civil law and Swazi law and custom', viewed 01 August 2013, from http://justgovernancegroup.org

Burns, J.M., 1978, Leadership, Harper \& Row, New York.

Constitution of the Kingdom of Swaziland, 2005, The Constitution of the Kingdom of Swaziland Act 2005, Act No, 001 of 2005, viewed 21 August 2013, from http:// www.ide.uniswa.sz/documents/resources/constitution2004.pdf

Éla, J.-M., 1988, My faith as an African, Orbis Books, Maryknoll.

Enns, F., 2011, 'The international ecumenical peace convocation: Towards an ecumenical theology of just-peace?', The Ecumenical Review 63(1), 44-53. http:// dx.doi.org/10.1111/j.1758-6623.2010.00092.x

Foreign \& Commonwealth, 2014, 'A case study on the September 2013 elections in Swaziland from the 2013 Human Rights and Democracy Report', viewed 08 July 2014, from https://www.gov.uk/government/case-studies/2013-elections

Gaylin, W., 1973, Feelings: Our vital signs, Harper \& Row, New York.

International Bar Association, 2013, Striving for democratic governance: An analysis of the Draft Swaziland Constitution, International Bar Association, London.

Integrated Regional Information Networks (IRIN) News, 2011, 'Swaziland: Orphans' doomsday scenario fails to materialize', viewed 21 August 2013, from http:// www.irinnews.org/report/91741/swaziland-Orphans-doomsday-scenario-failsto-materialize

Kalley, J., 2003, 'Swaziland election dossier, 2003 No. 1, October 2003', viewed 01 August 2013, from http://www.eisa.org.za/PDF/ED_Swaziland2003.pdf

Katongole, E., 2002, '"A different world right here, a world being gestated in the deeds of the everyday": The church with African theological imagination', Missionalia 30(2), 206-234.

Keepin, W. \& Brix, C., 2008, 'Divine duality | Reconciliation between women and men', Kosmos (spring/summer), 34-36.

Kennedy, D., 2000, 'A contextual theology of leadership', Theological Education 37(1), 63-72.

King, M.L., 1967, 'Domestic impact of the war November 1967: National labor leadership assembly for peace', viewed 01 August 2013, from http://www.aavw.org/

Langwenya, M., 2013, Swaziland justice sector and the rule of law: A review by AfriMAP and the open society initiative for Southern Africa, Open Society Foundation, Johannesburg.

Mabuza, K., 2013, 'Permanent Mission of the Kingdom of Swaziland to the United Nations', statement by H.E. MS. Khangeziwe Mabuza, Principal Secretary at the Deputy Prime Minister's Office as Head of Delegation of the Kingdom of Swaziland, at the 57th Session of the Commission on the Status of Women New York, 11th March 2013, viewed 21 August 2013, from http://www.un.org/ womenwatch/daw/csw/

Magesa, L., 1997, African religion: The moral traditions of abundant life, Orbis Books, Maryknoll.

Manson, K.E., 2008, 'Comparing and contrasting liberal, communitarian and feminist approaches to resolving tensions between customary and constitutional law: The case of polygamy in Swaziland', viewed 01 August 2013, from http://eprints.ru.ac.za

Maxwell, J.C., 2007, The Maxwell leadership Bible, Thomas Nelson, Nashville.

Mugambi, J.N.K., 1995, From liberation to reconstruction: African Christian theology after the Cold War, East African Education Publishers, Nairobi.

Mwaura, P.N., 2005, 'Gender and power in African Christianity: African instituted churches and Pentecostal churches', in O.U. Kalu (ed.), African Christianity: An African story, pp. 410-445, University of Pretoria, Pretoria.

Njoroge, N.J., 2000, Kiama Kia Ngo: African Christian feminist ethic, Legon Theological Study Series, Legon. 
Oduyoye, M.A., 1986, Hearing and knowing: Theological reflections on Christianity in Africa, Orbis, Maryknoll.

Phiri, I.A., 1997, 'Doing theology in community: The case of African women theologians in the 1990s', Journal of Theology for Southern Africa 99(November), 68-76.

Phiri, I.A. \& Nadar, S., 2010, 'Talking back to religion and HIV \& AIDS using an African feminist missiological framework: Sketching the contours of the conversation', Journal of Constructive Theology 16(2), 8-24.

Phumaphi, J. \& Carey, L., 2007, 'Foreword', in K. Marshall \& M. van Saanen (eds.) Development and faith: Where mind, and soul work together, pp. xi-xii, World Bank, Washington.

Precept Austin, n.d., 'Word study: Sin', viewed 01 August 2013, from http://www. preceptaustin.org

Pui-lan, K., 1996, 'Mission', in L.M. Russel \& J.S. Clarkson (eds.), Dictionary of feminist theologies, pp. 185-186, Westminster John Knox Press, Louisville.
Pui-lan, K., 2004, 'Feminist theologies intercultural discourse', in S.F. Parsons (ed.) The Cambridge companion to feminist theology, pp. 23-39, Cambridge University Press, Cambridge.

Sundkler, B. \& Steed, C., 2000, A history of the church in Africa, Cambridge University Press, Cambridge. http://dx.doi.org/10.1017/CBO9780511497377

Van Schalkwyk, A., 2006, 'The indigenous law of contract with particular reference to the Swazi in the Kingdom of Swaziland', PhD dissertation, Department of Jurisprudence, University of South Africa.

Whelpton, van R., 1997, 'Swazi law and custom in the Kingdom of Swaziland', South African Journal of Ethnology 20(3), 145-154

World Council of Churches (WCC), 1991, Healing and wholeness: The churches' role in health, WCC, Geneva.

World Health Organization (WHO), 2012, 'Country cooperation strategy at a glance: Swaziland', viewed 01 August 2013, from http://www.unicef.org/infobycountry/ swaziland statistics.html 